\section{Evaluation of Additional}

\section{Sequential Boost Radiotherapy}

(RT) After Whole Breast

\section{Irradiation (WBI) for Patients}

with Early Breast Cancer (Ca)

\author{
Ferrat Dincoglan, Murat Beyzadeoglu, Omer Sager*, Selcuk \\ Demiral, Bora Uysal, Hakan Gamsiz, Onurhan Colak, Fatih \\ Ozcan and Bahar Dirican
}

Department of Radiation Oncology, University of Health Sciences, Gulhane Medical Faculty, Ankara, Turkey
Received: 30 May, 2020

Accepted: 12 June, 2020

Published: 13 June, 2020

*Corresponding author: Dr. Omer Sager, MD, Associate Professor of Radiation Oncology, Department of Radiation Oncology, University of Health Sciences, Gulhane Medical Faculty, 06018, Etlik, Kecioren, Ankara, Turkey, Tel: +90 312304 4683; Fax: +90 312304 4680; E-mail:omersager@gmail.com

Keywords: Breast cancer (Ca); Radiotherapy (RT); Boost; Whole breast irradiation (WBI); Breast conserving surgery (BCS)

ORCID: https://orcid.org/0000-0001-7866-2598

https://www.peertechz.com

\section{Check for updates}

\begin{abstract}
Breast cancer ( $\mathrm{Ca}$ ) comprises the most common cancer in females and constitutes a leading cause of cancer related deaths around the globe. Contemporary treatment protocols established by incorporation of accumulating high level evidence suggest multimodality therapy for patients suffering from breast Ca with combinations of surgery, radiotherapy (RT) and systemic treatment. Surgical options for management of breast cancer typically include breast conserving surgery (BCS) or mastectomy. In current treatment practice, BCS is used as a viable surgical modality for breast Ca management. RT after BCS has been widely adopted for management of the vast majority of patients with breast Ca particularly to achieve improved local control as suggested by collaborative group studies and metaanalyses. Although alternative dose-fractionation schemes may be considered for management of some patients, current widely accepted practice includes the use of conventionally fractionated RT after BCS for breast Ca. Whole breast irradiation (WBI) constitutes a widely recognized breast Ca RT approach which is typically used to deliver a total dose of 45 to 50 Gy over 5 to 6 weeks in daily fractions of 1.8 to $2 \mathrm{~Gy}$. Hypofractionated RT schemes have also been widely accepted as a viable alternative to conventional fractionation with satisfactory treatment outcomes. A typical location for local recurrences of breast Ca includes the primary tumor site within the tumor bed or its vicinity, which justifies the delivery of additional boost dose focused on this area to improve local control rates particularly for patients with high-risk characteristics including younger age, large tumor size, higher grade, extensive intraductal component, close or positive surgical margins. Herein, we assess the utility of delivering an additional sequential boost RT after WBI for patients with early breast Ca in light of the literature.
\end{abstract}

\section{Introduction}

Breast cancer $(\mathrm{Ca})$ comprises the most common cancer in females and constitutes a leading cause of cancer related deaths around the globe $[1,2]$. Contemporary treatment protocols established by incorporation of accumulating high level evidence suggest multimodality therapy for patients suffering from breast Ca with combinations of surgery, Radiotherapy (RT) and systemic treatment. Nevertheless, there remain controversies for certain conditions such as the role of postmastectomy RT for subgroups of patients with T3No tumors or T1-T2 tumors with 1 to 3 positive axillary lymph nodes, and for patients receiving neoadjuvant chemotherapy before mastectomy [3-9]. Another potential focus of consideration is the role of adjuvant RT for elderly patients deemed at lower risk of recurrence with respect to hormonal receptor status, axillary nodal status, tumor size, grade, lymphovascular invasion, and surgical margin status [10-12]. These considerations primarily stem from a motivation for omission of RT when there is no substantial benefit to improve the therapeutic ratio. Sparing of highly selected subgroups of patients from RT may have potential implications for improved 
quality of life due to elimination of radiation induced adverse effects. Also, cumulative costs of treatment may be reduced along with the RT facility workloads. Hypofractionated RT schemes have gained widespread popularity given the patient and treatment facility convenience along with shorter treatment courses offering satisfactory therapeutic outcomes. Herein, we focus on another critical aspect of multidisciplinary breast Ca management. We assess the utility of delivering an additional sequential boost RT after Whole Breast Irradiation (WBI) for patients with early breast Ca in light of the recent advances and existing literature.

\section{Breast Conserving Surgery (BCS) as an alternative to mastectomy}

Surgical options for management of breast cancer typically include BCS or mastectomy. Several factors may have a role in selection of either BCS or mastectomy for a given patient such as patient and treatment characteristics, considerations regarding cosmesis, adverse effects, tumor control and patient preferences. Regarding the outcomes of management with these 2 surgical modalities, BCS and mastectomy were found to achieve comparable efficacy as supported by high level evidence from randomized trials [13-15]. Also, there have been some other studies focusing on favorable aspects of management with BCS [16-18]. In current treatment practice, BCS is used as a viable surgical modality for breast Ca management.

\section{Utilization of RT after BCS}

There has been thorough consideration for omission of RT after BCS in selected subgoups of highly selected patients with favorable characteristics regarding the hormonal receptor status, axillary nodal status, tumor size, grade, lymphovascular invasion, and surgical margin status [1012,19-21]. Nevertheless, RT after BCS has been widely adopted for management of the vast majority of patients with breast Ca particularly to achieve improved local control as suggested by collaborative group studies and metaanalyses [22-25].

\section{Dose and fractionation for RT after BCS}

Utility of Accelerated Partial Breast Irradiation (APBI) and hypofractionated RT schedules for breast Ca management has been investigated [26-33]. Although these alternative dosefractionation schemes may be considered for management of some patients, current widely accepted practice includes the use of conventionally fractionated RT after BCS for breast Ca. Whole Breast Irradiation (WBI) constitutes a widely recognized breast Ca RT approach which is typically used to deliver a total dose of 45 to 50 Gy over 5 to 6 weeks in daily fractions of 1.8 to 2 Gy. Nevertheless, hypofractionated RT schemes have also been widely accepted as a viable alternative to conventional fractionation with satisfactory treatment outcomes and widespread adoption. Rationale of hypofractionation stems from the moderately low alpha/beta ratio of breast tumors together with other potential favorable features of hypofractionated regimens including patient and treatment facility convenience.

\section{Role of an additional boost dose after WBI: review of evidence}

A typical location for local recurrences of breast Ca includes the primary tumor site within the tumor bed or its vicinity, which justifies the delivery of additional boost dose focused on this area to improve local control rates particularly for patients with high-risk characteristics including younger age, large tumor size, higher grade, extensive intraductal component, close or positive surgical margins [34-52].

Results of a randomized French trial conducted between 1986 and 1992 including 1024 patients with early breast Ca revealed that an additional boost dose of $10 \mathrm{~Gy}$ delivered after WBI significantly reduced the risk of early local recurrence without serious deterioration in cosmetic outcomes [37].

European Organisation for Research and Treatment of Cancer (EORTC) has assessed the utility of delivering a 16 Gy boost dose directed at the tumor bed after WBI in a phase III randomized trial conducted between 1989 and 1996 [44]. Randomization of 5569 patients was achieved. The results at 20 year follow-up revealed that the risk of Ipsilateral Breast Tumor Recurrence (IBTR) was decreased by incorporation of the boost in management with the largest absolute benefit for younger patients $[44,48]$.

A study focusing on a subgroup of the EORTC boost vs no boost trial by Jones et al. revealed that young age and high grade invasive ductal cancer were significant risk factors for local recurrence while margin status did not have significant influence [45]. The boost dose of $16 \mathrm{~Gy}$ had a significant effect on reduction of the negative influence of high grade invasive Ca and young age [45].

The recent Cochrane review of 5 randomize controlled trials suggested improved local control rates by use of an additional boost dose to the tumor bed with worsened cosmetic outcomes when assessed by a panel [50].

IBTR may serve as a predictor of prognosis for breast Ca. A study by Komoike et al. reported a correlation between IBTR and subsequent development of distant metastases for patients with early breast $\mathrm{Ca}$ [53].

From the opponent standpoint, unfavorable aspects of delivering an additional boost dose may include increased treatment cost and workload, fibrosis, and worse cosmetic results which may have a negative effect on patient satisfaction, psychology and quality of life [39,44,54-57].

In the recent American Society for Radiation Oncology (ASTRO) evidence based guideline, delivery of an additional boost dose to the tumor bed is suggested for patients $\leq 50$ years of age with any grade Ca [58].

\section{Recent advances and future perspectives}

Recent years have witnessed substantial advances in radiation oncology including Image Guided Radiation Therapy (IGRT), Adaptive Radiation Therapy (ART), Intensity Modulated Radiation Therapy (IMRT) and Breathing Adapted Radiation Therapy (BART), with encouraging potential to further improve treatment outcomes [59-67]. In the context of systemic dissemination, radiosurgical applications in the 
forms of Stereotactic Radiosurgery (SRS), Hypofractionated Stereotactic Radiation Therapy (HFSRT), and Stereotactic Body Radiation Therapy (SBRT) offer safe and effective management of intracranial and extracranial dissemination [68-92].

\section{Conclusion}

There is growing body of evidence supporting the use of an additional boost dose to the tumor bed for patients receiving WBI after BCS. Rationale for delivery of the additional boost dose includes eradication of microscopic tumor cells located most likely at the tumor bed or in close vicinity to improve local control. A critical unfavorable aspect of additional boost dose may include impaired cosmesis, however, this may be partly accounted for by incorporation of contemporary RT rechniques with improved normal tissue sparing capability.

\section{References}

1. Mubarik S, Wang F, Fawad M, Wang Y, Ahmad, I et al. (2020) Trends and Projections in Breast Cancer Mortality among four Asian countries (19902017): Evidence from five Stochastic Mortality Models. Sci Rep 10: 5480. Link: https://go.nature.com/2zxfcAC

2. Torre LA, Siegel RL, Ward EM, Jemal A (2016) Global Cancer Incidence and Mortality Rates and Trends--An Update. Cancer Epidemiol Biomarkers Prev 25 16-27. Link: https://bit.ly/3cWqgVt

3. Johnson ME, Handorf EA, Martin JM, Hayes SB (2014) Postmastectomy radiation therapy for T3NO: a SEER analysis. Cancer 120: 3569-3574. Link: https://bit.ly/2XXZisd

4. McCammon R, Finlayson C, Schwer A, Rabinovitch R (2008) Impact of postmastectomy radiotherapy in T3NO invasive carcinoma of the breast: a Surveillance, Epidemiology, and End Results database analysis. Cancer 113: 683-689. Link: https://bit.ly/3fl5Nvg

5. Yan W, Christos P, Nori D, Chao KS, Ravi A (2013) Is there a cause-specific survival benefit of postmastectomy radiation therapy in women younger than age 50 with T3NO invasive breast cancer? A SEER database analysis: outcomes by receptor status/race/age: analysis using the $\mathrm{NCI}$ Surveillance, Epidemiology, and End Results (SEER) database. Am J Clin Oncol 36: 552-557. Link: https://bit.ly/2Yvb5gP

6. Everett AS, Boggs DH, De Los Santos JF (2018) Postmastectomy Radiation Therapy: Are We Ready to Individualize Radiation? Int J Breast Cancer 2018: 1402824. Link: https://bit.ly/2MVTKZc

7. Montero Á, Ciérvide R, Poortmans P (2019) When Can We Avoid Postmastectomy Radiation Following Primary Systemic Therapy? Curr Oncol Rep 2019 21: 95. Link: https://bit.ly/30EExng

8. Huang EH, Tucker SL, Strom EA, McNeese MD, Kuerer HM, et al. (2004) Postmastectomy radiation improves local-regional control and survival for selected patients with locally advanced breast cancer treated with neoadjuvant chemotherapy and mastectomy. J Clin Oncol 22: 4691-4699. Link: https://bit.ly/30P8Esr

9. Fowble BL, Einck JP, Kim DN, McCloskey S, Mayadev J, et al. (2012) Role of postmastectomy radiation after neoadjuvant chemotherapy in stage II-III breast cancer. Int J Radiat Oncol Biol Phys 83: 494-503. Link: https://bit.ly/2YypdWq

10. Kunkler IH, Williams LJ, Jack WJ, Cameron DA, Dixon JM, et al. (2015) Breastconserving surgery with or without irradiation in women aged 65 years or older with early breast cancer (PRIME II): a randomised controlled trial. Lancet Oncol 16: 266-273. Link: https://bit.ly/2B4eGul

11. Hughes KS, Schnaper LA (2015) Can older women with early breast cancer avoid radiation? Lancet Oncol 16: 235-237. Link: https://bit.ly/30CEqsn
12. Kaidar-Person O, Poortmans P, Kuten A, Morgan DA (2015) Radiotherapy for elderly patients with low-risk breast cancer. Lancet Oncol 16: e196-197. Link: https://bit.ly/3hv524L

13. Early Breast Cancer Trialists' Collaborative Group (2002) Radiotherapy for early breast cancer. Cochrane Database Syst Rev 2: CD003647.

14. Fisher B, Anderson S, Bryant J, Margolese RG, Deutsch M,et al. (2002) Twentyyear follow-up of a randomized trial comparing total mastectomy, lumpectomy, and lumpectomy plus irradiation for the treatment of invasive breast cancer. $\mathrm{N}$ Engl J Med 347: 1233-1241. Link: https://bit.ly/37x4DKj

15. Litière S, Werutsky G, Fentiman IS, Rutgers E, Christiaens MR, et al. (2012) Breast conserving therapy versus mastectomy for stage I-II breast cancer: 20 year follow-up of the EORTC 10801 phase 3 randomised trial. Lancet Oncol 13: 412-419. Link: https://bit.ly/3hq39W

16. Corradini S, Reitz D, Pazos M, Schönecker S, Braun M, et al. (2019) Mastectomy or Breast-Conserving Therapy for Early Breast Cancer in RealLife Clinical Practice: Outcome Comparison of 7565 Cases. Cancers (Basel). 11: E160. Link: https://bit.ly/2XYs3oY

17. Chen K, Liu J, Zhu L, Su F, Song E, et al. (2015) Comparative effectiveness study of breast-conserving surgery and mastectomy in the general population: A NCDB analysis. Oncotarget 6: 40127-40140. Link: https://bit.ly/2Avsmyt

18. Onitilo AA, Engel JM, Stankowski RV, Doi SA (2015) Survival Comparisons for Breast Conserving Surgery and Mastectomy Revisited: Community Experience and the Role of Radiation Therapy. Clin Med Res 13: 65-73. Link: https://bit.ly/3dZSMGW

19. Wu SG, Zhang WW, Sun JY, Li FY, Chen YX, et al. (2018) Omission of Postoperative Radiotherapy in Women Aged 65 Years or Older With Tubular Carcinoma of the Breast After Breast-Conserving Surgery. Front Oncol 8: 190 Link: https://bit.ly/2UD6DeX

20. Hughes KS, Schnaper LA, Bellon JR, Cirrincione CT, Berry DA, et al. (2013) Lumpectomy plus tamoxifen with or without irradiation in women age 70 years or older with early breast cancer: long-term follow-up of CALGB 9343. J Clin Oncol 31: 2382-2387. Link: https://bit.ly/30zHk13

21. Hughes KS, Schnaper LA, Berry D, Cirrincione C, McCormick B, et al. (2004) Lumpectomy plus tamoxifen with or without irradiation in women 70 years of age or older with early breast cancer. N Engl J Med 351: 971-977. Link: https://bit.ly/3dZkuDY

22. Matuschek C, Bölke E, Haussmann J, Mohrmann S, Nestle-Krämling C, et al. (2017) The benefit of adjuvant radiotherapy after breast conserving surgery in older patients with low risk breast cancer- a metaanalysis of randomized trials. Radiat Oncol 12: 60. Link: https://bit.ly/3hiq86d

23. van de Water W, Bastiaannet $E$, Scholten AN, Kiderlen $M$, de Craen AJ, et al. (2014) Breast-conserving surgery with o without radiotherapy in older breast patients with early stage breast cancer: a systematic review and meta-analysis. Ann Surg Oncol 21: 786-794. Link: https://bit.ly/30zw2tL

24. Early Breast Cancer Trialists' Collaborative Group (EBCTCG), Darby S, McGale P, Correa C, Taylor C, et al. (2011) Effect of radiotherapy after breastconserving surgery on 10-year recurrence and 15year breast cancer death: meta-analysis of individual patientdata for 10,801 women in 17 randomised trials. Lancet 378: 1707-1716. Link: https://bit.ly/2MTtzSP

25. Holli K, Hietanen P, Saaristo R, Huhtala H, Hakama M, et al. (2009) Radiotherapy after segmental resection of breast cancer with favorable prognostic features: 12-year follow-up results of a randomized trial. J Clin Oncol 27: 927-932. Link: https://bit.ly/3flu9Ag

26. Moran MS, Truong PT (2020) Hypofractionated radiation treatment for breast cancer: The time is now. Breast $J$ 26: 47-54. Link: https://bit.ly/3dWoogU 
27. Ohri N, Haffty BG (2018) Alternatives to Standard Fractionation Radiation Therapy After Lumpectomy: Hypofractionated Whole-Breast Irradiation and Accelerated Partial-Breast Irradiation. Surg Oncol Clin N Am 27: 181-194. Link: https://bit.ly/2UFY08b

28. Shaikh F, Chew J, Hochman T, Purswani J, Maisonet O, et al. (2018) Hypofractionated Whole-Breast Irradiation in Women Less Than 50 Years Old Treated on 4 Prospective Protocols. Int J Radiat Oncol Biol Phys 101: 11591167. Link: https://bit.ly/2B7umwY

29. Pazos M, Schönecker S, Reitz D, Rogowski $P$, Niyazi $M$, et al. (2018) Recent Developments in Radiation Oncology: An Overview of Individualised Treatment Strategies in Breast Cancer Breast Care (Basel) 13: 285-291. Link: https://bit.ly/2MVKX9m

30. Gupta A, Ohri N, Haffty BG (2018) Hypofractionated radiation treatment in the management of breast cancer. Expert Rev Anticancer Ther 18: 793-803. Link: https://bit.ly/3dXWr8v

31. Kirova YM (2016) Radiation therapy (RT) after breast-conserving surgery (BCS) in 2015--The year of radiation therapy advances. Eur J Surg Oncol 42: 437-440. Link: https://bit.ly/37oSR4C

32. Koulis TA, Phan T, Olivotto IA (2015) Hypofractionated whole breast radiotherapy: current perspectives. Breast Cancer (Dove Med Press) 7: 363-370. Link: https://bit.ly/30zwDeZ

33. Holloway CL, Panet-Raymond V, Olivotto I (2010) Hypofractionation should be the new 'standard' for radiation therapy after breast conserving surgery. Breast 19: 163-167. Link: https://bit.ly/2UzBI8H

34. Wickberg A, Holmberg L, Adami HO, Magnuson A, Villman K, et al. (2014) Sector resection with or without postoperative radiotherapy for stage I breast cancer: 20-year results of a randomized trial. J Clin Oncol 32: 791-797. Link: https://bit.ly/2MWhnRj

35. Clark RM, McCulloch PB, Levine MN, Lipa M, Wilkinson RH, et al. (1992) Randomized clinical trial to assess the effectiveness of breast irradiation following lumpectomy and axillary dissection for node-negative breast cancer J Natl Cancer Inst 84: 683-689. Link: https://bit.ly/30AxIIQ

36. Forrest AP, Stewart HJ, Everington D, Prescott RJ, McArdle CS, et al (1996) Randomised controlled trial of conservation therapy for breast cancer: 6-year analysis of the Scottish Trial. Lancet 348: 708-713. Link: https://bit.ly/2XYsXSo

37. Romestaing $P$, Lehingue $Y$, Carrie $C$, Coquard R, Montbarbon X, et al. (1997) Role of a 10-Gy boost in the conservative treatment of early breast cancer results of a randomized clinical trial in Lyon, France. J Clin Oncol 15: 963-968. Link: https://bit.ly/3fjFXrj

38. Polgár C, Fodor J, Major T, Orosz Z, Németh G (2001) The role of boost irradiation in the conservative treatment of stage I-II breast cancer. Pathol Oncol Res 7: 241-50. Link: https://bit.ly/2B1CG12

39. Bartelink H, Horiot JC, Poortmans $P$, Struikmans $H$, Van den Bogaert W, et al. (2001) Recurrence rates after treatment of breast cancer with standard radiotherapy with or without additional radiation. N Engl J Med 345: 13781387. Link: https://bit.ly/2YtPIwp

40. Polgár C, Fodor J, Orosz Z, Major T, Takácsi-Nagy Z, et al. (2002) Electron and high-dose-rate brachytherapy boost in the conservative treatment of stage I-II breast cancer first results of the randomized Budapest boost trial. Strahlenther Onkol 178: 615-623. Link: https://bit.ly/3hsfCJM

41. Arriagada R, Lê MG, Guinebretière JM, Dunant A, Rochard F, et al. (2003) Late local recurrences in a randomized trial comparing conservative treatment with total mastectomy in early breast cancer patients. Ann Oncol 14: 1617-1622. Link: https://bit.ly/3fi1xwq

42. Graham $P$, Fourquet A (2006) Placing the boost in breast-conservation radiotherapy: A review of the role, indications and techniques for breast-boost radiotherapy. Clin Oncol (R Coll Radiol) 18: 210-219. Link: https://bit.ly/2BVaX2q
43. Arriagada R, Le MG, Dunant A, Tubiana M, Contesso G (2006) Twenty-five years of follow-up in patients with operable breast carcinoma: correlation between clinicopathologic factors and the risk of death in each 5 year period. Cancer 106: 743-750. Link: https://bit.ly/2B8M8Q7

44. Bartelink H, Horiot JC, Poortmans PM, Struikmans H, Van den Bogaert W et al. (2007) Impact of a higher radiation dose on local control and survival in breast-conserving therapy of early breast cancer: 10-year results of the randomized boost versus no boost EORTC 22881-10882 trial. J Clin Oncol 25 3259-3265. Link: https://bit.ly/3d2asAp

45. Jones HA, Antonini N, Hart AA, Peterse JL, Horiot JC, et al. (2009) Impact of pathological characteristics on local relapse after breast-conserving therapy: a subgroup analysis of the EORTC boost versus no boost trial. J Clin Oncol 27: 4939-4947. Link: https://bit.ly/2YJX2nV

46. Livi L, Borghesi S, Saieva C, Fambrini M, lannalfi A, et al. (2009) Benefit of radiation boost after whole-breast radiotherapy. Int $\mathrm{J}$ Radiat Oncol Biol Phys 75: 1029-1034. Link: https://bit.ly/3dWp8Te

47. Hau E, Browne LH, Khanna S, Cail S, Cert G, et al. (2012) Radiotherapy breast boost with reduced whole-breast dose is associated with improved cosmesis: the results of a comprehensive assessment from the St. George and Wollongong randomized breast boost trial. Int $\mathrm{J}$ Radiat Oncol Biol Phys 82: 682-689. Link: https://bit.ly/3dYoeFJ

48. Bartelink H, Maingon P, Poortmans P, Weltens C, Fourquet A, et al. (2015) Wholebreast irradiation with or without a boost for patients treated with breastconserving surgery for early breast cancer: 20-year follow-up of a randomised phase 3 trial. Lancet Oncol 16:47-56. Link: https://bit.ly/2B4gfsd

49. Vrieling C, van Werkhoven E, Maingon P, Poortmans P, Weltens C, et al. (2017) Prognostic Factors for Local Control in Breast Cancer After Long-term Followup in the EORTC Boost vs No Boost Trial: A Randomized Clinical Trial. JAMA Oncol 3: 42-48. Link: https://bit.ly/3dXXiWL

50. Kindts I, Laenen A, Depuydt T, Weltens C (2017) Tumour bed boost radiotherapy for women after breast-conserving surgery. Cochrane Database Syst Rev 11: CD011987. Link: https://bit.ly/3hkpwNk

51. Ono Y, Yoshimura M, Hirata K, Yamauchi C, Toi M, et al. (2019) The impact of age on the risk of ipsilateral breast tumor recurrence after breastconserving therapy in breast cancer patients with a $>5 \mathrm{~mm}$ margin treated without boost irradiation. Radiat Oncol 14: 121. Link: https://bit.ly/3flgAFw

52. Suzuki R, Yoshida M, Oguchi M, Yoshioka Y, Tokumasu K, et al. (2020) Efficacy of radiation boost after breast-conserving surgery for breast cancer with focally positive, tumor-exposed margins. J Radiat Res. Link: https://bit.ly/3d4qABO

53. Komoike Y, Akiyama F, lino Y, Ikeda T, Akashi-Tanaka S, et al. (2006) Ipsilateral breast tumor recurrence (IBTR) after breast-conserving treatment for early breast cancer: risk factors and impact on distant metastases. Cancer 106: 3541. Link: https://bit.ly/3d2aUyB

54. Poortmans PM, Collette L, Horiot JC, Van den Bogaert WF, Fourquet A, et al (2009) Impact of the boost dose of 10 Gy versus 26 Gy in patients with early stage breast cancer after a microscopically incomplete lumpectomy: 10-year results of the randomised EORTC boost trial. Radiother Oncol 90: 80-85. Link: https://bit.ly/2XXWYSg

55. Poortmans PM, Collette L, Bartelink H, Struikmans $H$, Van den Bogaert WF et al. (2008) The addition of a boost dose on the primary tumour bed after lumpectomy in breast conserving treatment for breast cancer. A summary of the results of EORTC 22881-10882 "boost versus no boost" trial. Cance Radiother 12: 565-570. Link: https://bit.ly/2Y1QCRX

56. Vrieling C, Collette L, Fourquet A, Hoogenraad WJ, Horiot JC, et al. (1999) The influence of the boost in breast-conserving therapy on cosmetic outcome in the EORTC "boost versus no boost" trial. EORTC Radiotherapy and Breast Cancer Cooperative Groups. European Organization for Research and Treatment of Cancer. Int J Radiat Oncol Biol Phys 45: 677-685. Link: https://bit.ly/2MW9IIQ 
57. Al-Ghazal SK, Fallowfield L, Blamey RW (1999) Does cosmetic outcome from treatment of primary breast cancer influence psychosocial morbidity? Eur $\mathrm{J}$ Surg Oncol 25: 571-573. Link: https://bit.ly/2B0EbN8

58. Smith BD, Bellon JR, Blitzblau R, Freedman G, Haffty B, et al. (2018) Radiation therapy for the whole breast: executive summary of an American Society for Radiation Oncology (ASTRO) evidence-based guideline. Pract Radiat Oncol 8: 145-152. Link: https://bit.ly/3hkgGzj

59. Sager O, Dincoglan F, Demiral S, Uysal B, Gamsiz H, et al. (2019) Breathing adapted radiation therapy for leukemia relapse in the breast: $\mathrm{A}$ case report. World J Clin Oncol 10: 369-374. Link: https://bit.ly/2UEbcWk

60. Sager O, Dincoglan F, Uysal B, Demiral S, Gamsiz H, et al. (2018) Evaluation of adaptive radiotherapy (ART) by use of replanning the tumor bed boost with repeated computed tomography (CT) simulation after whole breast irradiation (WBI) for breast cancer patients having clinically evident seroma. Jpn J Radiol 36: 401-406. Link: https://bit.ly/2XYulV6

61. Demiral S, Sager O, Dincoglan F, Uysal B, Gamsiz H, et al. (2017) Dosimetric Evaluation of Breathing-Adapted Radiotherapy for Right-Sided Breast Cancer. Canc Therapy \& Oncol Int J 7: 555713. Link: https://bit.ly/2XV6XHY

62. Sager O, Dincoglan F, Uysal B, Demiral S, Gamsiz H, et al. (2017) Splenic Irradiation: A Concise Review of the Literature. J App Hem BI Tran 1: 101 Link: https://bit.ly/3hoOtas

63. Sager O, Beyzadeoglu M, Dincoglan F, Demiral S, Uysal B, et al. (2015) Adaptive splenic radiotherapy for symptomatic splenomegaly management in myeloproliferative disorders. Tumori 101: 84-90. Link: https://bit.ly/37pzxnS

64. Dincoglan F, Beyzadeoglu M, Sager O, Oysul K, Kahya YE, et al. (2013) Dosimetric evaluation of critical organs at risk in mastectomized left-sided breast cancer radiotherapy using breath-hold technique. Tumori 99: 76-82. Link: https://bit.ly/37o5Fs4

65. Uysal B, Beyzadeoğlu M, Sager O, Dinçoğlan F, Demiral S, et al. (2013) Dosimetric evaluation of intensity modulated radiotherapy and 4-field 3-d conformal radiotherapy in prostate cancer treatment. Balkan Med J 30: 54-57. Link: https://bit.ly/2B41WDQ

66. Sager O, Beyzadeoglu M, Dinçoğlan F, Oysul K, Kahya YE, et al. (2012) The Role of Active Breathing Control-Moderate Deep Inspiration Breath-Hold (ABC$\mathrm{mDIBH}$ ) Usage in non-Mastectomized Left-sided Breast Cancer Radiotherapy: A Dosimetric Evaluation UHOD-Uluslararasi Hematoloji Onkoloji Dergisi 22 147-155. Link: https://bit.ly/3hlxfKZ

67. Sager O, Beyzadeoglu M, Dincoglan F, Oysul K, Kahya YE, et al. (2012) Evaluation of active breathing control-moderate deep inspiration breath-hold in definitive non-small cell lung cancer radiotherapy. Neoplasma 59: 333-340. Link: https://bit.ly/3cVtnNh

68. Dincoglan F, Beyzadeoglu M, Sager O, Demiral S, Uysal B, et al. (2020) A Concise Review of Irradiation for Temporal Bone Chemodectomas (TBC). Arch Otolaryngol Rhinol 6: 016-020. Link: https://bit.ly/3dZ4WQA

69. Sager O, Beyzadeoglu M, Dincoglan F, Demiral S, Gamsiz H, et al. (2020) Multimodality management of cavernous sinus meningiomas with less extensive surgery followed by subsequent irradiation: Implications for an improved toxicity profile. J Surg Surgical Res 6: 056-061.

70. Beyzadeoglu M, Sager O, Dincoglan F, Demiral S, Uysal B, et al. (2020) Single Fraction Stereotactic Radiosurgery (SRS) versus Fractionated Stereotactic Radiotherapy (FSRT) for Vestibular Schwannoma (VS). J Surg Surgical Res 6: 062-066.

71. Dincoglan F, Sager O, Uysal B, Demiral S, Gamsiz H, et al. (2019) Evaluation of hypofractionated stereotactic radiotherapy (HFSRT) to the resection cavity after surgical resection of brain metastases: A single center experience. Indian J Cancer 56: 202-206.
72. Dincoglan F, Sager O, Demiral S, Gamsiz H, Uysal B, et al. (2019) Fractionated stereotactic radiosurgery for locally recurrent brain metastases after failed stereotactic radiosurgery. Indian J Cancer 56: 151-156. Link: https://bit. ly/3fn3asy

73. Demiral S, Dincoglan F, Sager O, Uysal B, Gamsiz H, et al. (2018) Contemporary Management of Meningiomas with Radiosurgery. Int J Radiol Imaging Technol 4: 187-190. Link: https://bit.ly/37qYlq4

74. Dincoglan F, Sager O, Demiral S, Uysal B, Gamsiz H, et al. (2017) Radiosurgery for recurrent glioblastoma: A review article. Neurol Disord Therap 1: 1-5. Link: https://bit.ly/2UECGLr

75. Demiral S, Dincoglan F, Sager O, Gamsiz H, Uysal B, et al. (2016) Hypofractionated stereotactic radiotherapy (HFSRT) for who grade I anterior clinoid meningiomas (ACM). Jpn J Radiol 34: 730-737. Link: https://bit. ly/2XY3zvL

76. Dincoglan F, Beyzadeoglu M, Sager O, Demiral S, Gamsiz H, et al. (2015) Management of patients with recurrent glioblastoma using hypofractionated stereotactic radiotherapy. Tumori 101: 179-184. Link: https://bit.ly/3hnhD9L

77. Sager O, Dincoglan F, Beyzadeoglu M (2015) Stereotactic radiosurgery of glomus jugulare tumors: current concepts, recent advances and future perspectives. CNS Oncol 4: 105-114. Link: https://bit.ly/3fhelOf

78. Gamsiz H, Beyzadeoglu M, Sager O, Demiral S, Dincoglan F, et al. (2015) Evaluation of stereotactic body radiation therapy in the management of adrenal metastases from non-small cell lung cancer. Tumori 101: 98-103. Link: https://bit.ly/3ffjlYU

79. Demiral S, Beyzadeoglu M, Sager O, Dincoglan F, Gamsiz H, et al. (2014) Evaluation of linear accelerator (linac)-based stereotactic radiosurgery (srs) for the treatment of craniopharyngiomas. UHOD-Uluslararasi HematolojiOnkoloji Dergisi 24: 123-129. Link: https://bit.ly/3hq6Vzm

80. Sager O, Beyzadeoglu M, Dincoglan F, Gamsiz H, Demiral S, et al. (2014) Evaluation of linear accelerator-based stereotactic radiosurgery in the management of glomus jugulare tumors. Tumori 100: 184-188. Link: https://bit.ly/3dZGeQ7

81. Dincoglan F, Sager O, Gamsiz H, Uysal B, Demiral S, et al. (2014) Management of patients with $\geq 4$ brain metastases using stereotactic radiosurgery boos after whole brain irradiation. Tumori 100: 302-306. Link: https://bit.ly/30C2viV

82. Gamsiz H, Beyzadeoglu M, Sager O, Dincoglan F, Demiral S, et al. (2014) Management of pulmonary oligometastases by stereotactic body radiotherapy. Tumori 100: 179-183. Link: https://bit.ly/3hkihoN

83. Sager O, Beyzadeoglu M, Dincoglan F, Uysal B, Gamsiz H, et al. (2014) Evaluation of linear accelerator (LINAC)-based stereotactic radiosurgery (SRS) for cerebral cavernous malformations: A 15-year single-center experience. Ann Saudi Med 34: 54-58. Link: https://bit.ly/3fejWtY

84. Dincoglan F, Beyzadeoglu M, Sager O, Uysal B, Demiral S, et al. (2013) Evaluation of linear accelerator-based stereotactic radiosurgery in the management of meningiomas: A single center experience. J BUON 18: 717722. Link: https://bit.ly/3cZIYLM

85. Demiral S, Beyzadeoglu M, Uysal B, Oysul K, Kahya YE, et al. (2013) Evaluation of stereotactic body radiotherapy (SBRT) boost in the management of endometrial cancer. Neoplasma 60: 322-327. Link: https://bit.ly/2XWslwe

86. Sager O, Beyzadeoglu M, Dincoglan F, Demiral S, Uysal B, et al. (2013) Management of vestibular schwannomas with linear accelerator-based stereotactic radiosurgery: A single center experience. Tumori 99: 617-622. Link: https://bit.ly/2MUJpfT

87. Surenkok S, Sager O, Dincoglan F, Gamsiz H, Demiral S, et al. (2012) Stereotactic radiosurgery in pituitary adenomas: A single center experience. UHOD-Uluslararasi Hematoloji-Onkoloji Dergisi 22: 255-260. Link: https://bit.ly/3hlyUQJ 
88. Dincoglan F, Beyzadeoglu M, Sager O, Oysul K, Sirin S, et al. (2012) Imageguided positioning in intracranial non-invasive stereotactic radiosurgery for the treatment of brain metastasis. Tumori 98: 630-635. Link: https://bit.ly/2B0tOZA

89. Dincoglan F, Sager O, Gamsiz H, Demiral S, Uysal B, et al. (2012) Management of arteriovenous malformations by stereotactic radiosurgery: A single center experience. UHOD-Uluslararasi Hematoloji-Onkoloji Dergisi 22: 107-112. Link: https://bit.ly/37qq3Zp
90. Dincoglan F, Sager O, Gamsiz H, Uysal B, Demiral S, et al. (2012) Stereotactic radiosurgery for intracranial tumors: A single center experience. Gulhane Med J 54: 190-198. Link: https://bit.ly/3cYmv1J

91. Sirin S, Oysul K, Surenkok S, Sager O, Dincoglan F, et al. (2011) Linear accelerator-based stereotactic radiosurgery in recurrent glioblastoma: A single center experience. Vojnosanit Pregl 68: 961-966. Link: https://bit.ly/3hqfBGb
Discover a bigger Impact and Visibility of your article publication with

Peertechz Publications

\section{Highlights}

* Signatory publisher of ORCID

* Signatory Publisher of DORA (San Francisco Declaration on Research Assessment)

* Articles archived in worlds' renowned service providers such as Portico, CNKI, AGRIS, TDNet, Base (Bielefeld University Library), CrossRef, Scilit, J-Gate etc.

* Journals indexed in ICMJE, SHERPA/ROMEO, Google Scholar etc.

- OAI-PMH (Open Archives Initiative Protocol for Metadata Harvesting)

* Dedicated Editorial Board for every journal

* Accurate and rapid peer-review process

* Increased citations of published articles through promotions

* Reduced timeline for article publication

Submit your articles and experience a new surge in publication services

(https://www.peertechz.com/submission).

Peertechz journals wishes everlasting success in your every endeavours.

Copyright: @ 2020 Dincoglan F, et al. This is an open-access article distributed under the terms of the Creative Commons Attribution License, which permits unrestricted use, distribution, and reproduction in any medium, provided the original author and source are credited. 